DOI: 10.33766/2524-0323.91.102-117

УДК 343.13.(477)

\section{Г. С. Крайник,}

кандидат юридичних наук, доцент кафедри кримінально-правових дисциплін та адміністративного права

Харківського університету

(м. Харків, Україна)

e-mail:vip.kraynik@ukr.net

iD https:/ / orcid.org/0000-00015703-4947

Т. С. Дунаєва,

кандидат юридичних наук, науковий співробітник

Науково-дослідного інституту вивчення проблем злочинності імені академіка

В. В. Сташиса НАПрН України (м. Харків, Україна)

e-mail: dunayevate@gmail.com

iD https:/ / orcid.org/0000-00033710-1318

\title{
ЯКІСТЬ КРИМІНАЛЬНОГО ПРОЦЕСУАЛЬНОГО ЗАКОНОДАВСТВА УКРАЇНИ, ЯКЕ РЕГУЛЮС ПІДСТАВИ ТА ПОРЯДОК ЗАСТОСУВАННЯ ЗАСТАВИ
}

У статті досліджено актуальні питання щодо застави як запобіжного заходу. Запропоновано законодавчі зміни до ст. 182 Кримінального процесуального кодексу України, які належним чином урегулюють питання застосування застави в Україні та усунуть існуючі недоліки. Обгрунтовано необхідність змін до ст. 182 Кримінального процесуального кодексу України та запровадження застави в негрошовій формі.

Чинну редакцію ст. 299 Кримінального процесуального кодексу України запропоновано вдосконалити шляхом надання можливості застосування застави при здійсненні кримінальних проступків.

Також убачається доцільним доповнити ч. 1 ст. 335 та ч. 9 ст. 335 Кримінального процесуального кодексу України положенням про рішення в резолютивній частині обвинувального вироку питання про повернення застави заставодавцю.

Запровадження вказаних пропозицій буде сприяти удосконаленню якості кримінального процесуального законодавства України щодо застави як запобіжного заходу.

Ключові слова: запобіжні заходи, застава, якість кримінального процесуального законодавства України, кримінальне процесуальне право України; кримінальне судочинство.

Постановка проблеми. На даний час застава в Україні, як запобіжний захід, призначається лише в грошовій формі, що обмежує права підозрюваних та обвинувачених на застосування цього запобіжного заходу.

Потребують розгляду пропозищія доповнення ч. 1 ст. 335 і ч. 9 ст. 335 Кримінального процесуального кодексу (далі - КПК) України положенням про вирішення в ре-

(C) Крайник Г. С.,

Дунаєва Т. С., 2020 
золютивній частині обвинувального вироку питання про повернення застави заставодавщю [1, с. 180], а також доречність чинного дозволу на застосування застави за умисні особливо тяжкі злочини.

Аналіз останніх досліджень і публікацій. Питання застави як запобіжного заходу законодавчо закріплено в ст. 180 чинного КПК України. Дану проблематику досліджували вітчизняні та зарубіжні науковці, зокрема: Н. А. Андронік [2; 13], Д. В. Вишньова [3], В. Ю. Дрозд [4], О. В. Ільченко [5], М. О. Карпенко та А. Р. Туманянщ [14], О. П. Кучинська та Н. О. Іверук [15], Т. О. Музиченко [16], В. О. Попелюшко [12], В. О. Січко [17], О. І. Тищенко [18] та ін. [10; 22; 23, с. 259-263; 30; 31; 32; 33]. Вважаємо, що норми чинного КПК України недостатньо якісно регулюють питання щодо застосування застави в Україні, а тому потребують реформування.

Формулювання цілей. Метою цієї статті є формулювання науково обгрунтованих пропозищій з удосконалення якості чинного кримінального процесуального законодавства України щодо застосування застави.

Виклад основного матеріалу. Запобіжні заходи - це частина заходів забезпечення кримінального провадження, спрямованих на забезпечення належної поведінки підозрюваного, обвинуваченого, засудженого шияхом певного обмеження їхніх особистих прав [6, с. 135].

Н. В. Глинська зазначає, що якість кримінально-процесуальних рішень є «оцінною категорією, яка означає порівняльний ступінь здатності правозастосовного акту виконати своє функціональне призначення в загальній динаміці кримінального провадження, задовольнити соціально-правові очікування від його реалізації відповідно до тих цілей і завдань, які ставились на момент його прийняття» [7, с. 565].

Під якістю кримінального процесуального законодавства ми розуміємо оцінну категорію, яка означає здатність КПК України та інших джерел кримінального процесуального законодавства України виконати свої завдання в кримінальному провадженні, задовольнити соціально-правові очікування від їх реалізації.

Ефективність законодавства в цілому та його галузей зумовлена виробленими теорією і практикою відповідними вимогами. Це, зокрема, наукова обгрунтованість і належна якість законів та інших нормативних актів, їх системна узгодженість, забезпечення реалізащії законодавства відповідними гарантіями й механізмами тощо [8, с. 40]

Л. М. Лобойко слушно зауважує, що якість кримінального процесуального законодавства має бути настільки високою, щоб виключити або максимально знизити рівень порушення прав і законних інтересів учасників кримінального провадження в перебігу здійснення процесуальних дій і прийняття кримінальних процесуальних рішень. Якісний кримінальний процесуальний закон легше виконувати, а тому й порушення його стають меншими за обсягом (кількістю), ніж неякісного закону. Також якість кримінального процесуального закону повинна забезпечувати справедливість кінщевого рішення [9, с. 30-31].

Ефективність кримінальної процесуальної діяльності залежить від багатьох чинників, але оскільки ця діяльність зводиться до застосування кримінального процесуального закону, то пріоритетне значення для досягнення кримінальнимпроцесом своєї мети є якість цього закону. Отже, якість кримінального процесуального закону становить основу забезпечення ефективності кримінальноїпроцесуальної діяльності. Нена- 
лежна якість закону призводить до зниження ефективності кримінальної процесуальної діяльності, бо суб' єкти діяльності, замість того, щоб ефективно іїздійснювати, з' ясовують, як діяти, щоб правильно застосувати ту чи іншу неякісну статтю закону [6, c. 108].

Л.М. Лобойко та О. А. Банчук поділяють запобіжні заходи на ізоляційні та неізоляційні, в основі такої класифікації - ступінь обмеження прав особи [6, с. 135]. До першої групи належать затримання і взяття під варту, а до другої - усі інші заходи, у тому числі застава.

В. Г. Крайнюк визначає заставу в кримінальному процесі як один з видів процесуального примусу, який застосовується у встановлених КПК Украӥни випадках, а також має психологічний аспект [20, с. 404]. Схожу думку висловили М. О. Карпенко й А. Р. Туманянщ, які відносять заставу до психолого-примусових запобіжних заходів. Суть таких запобіжних заходів полягає в тому, що на підозрюваного, обвинуваченого покладається моральне зобов' язання належної поведінки, яке забезпечується за допомогою психологічного впливу, спрямованого безпосередньо на нього або опосередковано, через третіх осіб [14, с. 91$]$.

Відповідно до ч. 5 ст. 182 КП ГК України «Застава», цей запобіжний захід застосовується незалежно від ступеня тяжкості вчиненого злочину, тобто за 3 категорії злочинів: нетяжкі, тяжкі та особливо тяжкі злочини (ч. 3 ст. 12 КК України) [35]. Причому, ст. 229 КПК України містить положення, що під час досудового розслідування кримінальних проступків не допускається застосування запобіжного заходу у виді застави.

До набрання чинності 1 липня 2020 р. Законом України «Про внесення змін до деяких законодавчих актів України щодо спрощення досудового розслідування окремих категорій кримінальних правопорушень» від 22 листопада 2018 р. № 2617-VIII [35] злочини поділялися на 4 категорії: невеликої тяжкості, середньої тяжкості, тяжкі, особливо тяжкі.

В. Г. Крайнюк дотримується точки зору, що застава є досить ефективною та дієвою, особливо при вчиненні корисливих злочинів [20, с. 403]. Враховуючи, що найбільшпоширеними злочинами в Украӥні є самезлочинипроти власності, актуальність питання, що досліджується, не викликає сумнівів.

В. О. Попелюшко вважає, що підстава застосування запобіжного заходу складна: по-перше, це наявність обгрунтованої підозри у вчиненні особою кримінального правопорушення, по-друге, наявність ризиків, які дають підстави вважати, що обвинувачений може здійснити зазначені дії (ст. I77 КПК України). При вирішенні питання про обрання запобіжного заходу слідчий, суддя, суд на підставі поданих сторонами кримінального провадження матеріалів повинен оцінити сукупність усіх юридично значущих обставин (ст. 178 КПК України) [12, с. 5].

Із зазначених положень випливає, що правовою підставою застосування застави як запобіжного заходу є наявність обгрунтованоїпідозри у вчиненні особою нетяжкого злочину, тяжкого або особливо тяжкого злочину (ч. 5 ст. 182 КПТК України) за наявності ризиків, які дають підстави вважати, що обвинувачений може здійснити зазначені дії.

Притому виникає питання про доцільність застосування застави за умисні особливо тяжкі злочини, за які можливе застосування тривалих строків позбавлення волі або довічного позбавлення волі. Вважаємо, що застосування застави у вказаних випад- 
ках не відповідає одному із завдань кримінального провадження - забезпеченню швидкого, повного та неупередженого розслідування й судового розгляду (ч. 1 ст. 2 КПК України), оскільки підозрюваний або обвинувачений може прагнути уникнути відповідальності, ухилятися від слідства та суду після внесення застави.

У зв'язку з викладеним, пропонуємо доповнити п. 3 ч. 5 ст. 182 КТІК України словом «необережного» і викласти в такій редакції: «щодо особи, підозрюваної чи обвинуваченої у вчиненні необережного особливо тяжкого злочину, - від вісімдесяти до трьохсот розмірів прожиткового мінімуму для працездатних осіб».

Порядок застосування застави визначається ч. 3 ст. 183, статтями 178, 182, 184-187, 192-194, 196, 200, 201, 203, 205, 304, 492 КТК України (визначено, що слідчий або прокурор вносять клопотання про застосування застави до місцевого суду, зміни або доповнення до такого клопотання, строки розгляду такого клопотання, хто може внести заставу, їі розміри, строки внесення, припинення тощо), а також ст. 7 Закону України «Про Державний бюджет України на 2020 рік» (де визначено розмір прожиткового мінімуму для працездатних осіб у 2020 р.) та Порядком внесення коштів на спеціальний рахунок у разі застосування застави як запобіжного заходу, затверджений постановою Кабінету Міністрів України від 11 січня 2012 р. № 15 [24].

У листі Вищого спеціалізованого суду України з розгляду цивільних та кримінальних справ «Про деякі питання порядку застосування запобіжних заходів під час досудового розслідування та судового провадження відповідно до Кримінального процесуального кодексу України» № 511-550/0/4-13 від 04.04.2013 р. у п. 16 роз'яснено питання щодо застосування застави. Наприклад, слідчому судді необхідно враховувати майновий стан підозрюваного, обвинуваченого та не допускати встановлення такого розміру застави як альтернативи триманню під вартою, що є завідомо непомірним для цієї особи та призводить до неможливості виконання застави. У кожному випадку застосування застави слід мати на увазі, що заставодавцем не може бути юридична особа державної або комунальної форми власності або така, що фінансується з місцевого, державного бюджету тощо [29].

Що стосується права заставодавця відмовитися від відповідного статусу з поверненням йому застави або заміни одного заставодавця на іншого, то це питання взагалі не вирішено в чинному законодавстві. Буквальне тлумачення ст. 182 КПК України дає підстави М. О. Карпенко та А. Р. Туманянщ стверджувати, що, лише одного разу погодившись стати застоводавцем і здійснивши безпосереднє внесення застави, людина більше не зможе в разі вірогідної в майбутньому неналежної поведінки підозрюваного, обвинуваченого, повернути внесені кошти [14, с. 92]. Водночас, Дискусійним є погляд науковців, що застава підлягає обов' язковій зміні в разі відповідного волевиявлення хоча б одного учасника цих правовідносин, тому що втрата взаємної довіри або настання інших непередбачуваних обставин має наслідком неефективність їх застосування [14, с. 92-93]. Ідеться про випадки, коли заставу, замість підозрюваного або обвинуваченого, внесла інша особа, яка згодом втратила довіру до підозрюваного або обвинуваченого чи з різних причин вирішила повернути внесену заставу. Дискусійність зазначеного погляду полягає в тому, що таке повернення застави суперечило б ч. 11 ст. 182 КПК України, де зазначено: «Застава, що не була звернена в дохід держави, повертається підозрюваному, обвинуваченому, заставодавцю після припинення дії 
цьго запобіжного заходу. Інакше кажучи, застава не може бути повернута заставодавцю до припинення цього запобіжного заходу. Інше вирішення цього питання потребує суттєвих змін у чинному кримінальному процесуальному законодавствы України.

Іншим важливим питанням удосконалення порядку застосування застави є можливість відновлення застави в негрошовій формі, що була передбачена в КПК України 1960 р. Н. А. Андронік вважає, що обрання предметом застави не грошей, а нерухомого майна ускладнить роботу слідчих [13, с. 35]. Не заперечуючи, що визнання застави в негрошовій формі ускладнить роботу слідчих та судлів, вважаємо, що запровадження застави в негрошовій формі цілком відповідає такій загальній засаді кримінального провадження, як верховенство права (ст. 8 КПК України), оскыльки, відповідно до принщипу верховенства права людина, іï права та свободи визнаються найвищими цінностями та визначають зміст і спрямованість діяльності держави. Зокрема, при визнанні застави в негрошовій формі непотрібно буде продавати нерухоме або рухоме майно, що належить обвинуваченому або підозрюваному, який не має достатніх готівкових коштів для внесення застави.

У КПК України 1960 р. та постанові Пленуму ВСУ «Про практику застосування судами застави як запобіжного заходу» від 26.03.1999 р. № 6 йшлося про можливість застосування застави в негрошовій формі [25]. Також таку можливість, з огляду на кращий захист прав людини, не заперечували науковці. Існує думка, що при застосуванні запобіжних заходів не повинні порушуватися права не тільки підозрюваного чи обвинуваченого, а й права і свободи інших осіб, зокрема членів родин підозрюваного чи обвинуваченого [26].

Для Свропейського Суду з прав людини важливим є не лише інтереси правосудця, але й приватний інтерес особи, що піддається кримінальному переслідуванню, намагається знайти оптимальний баланс. Він виходить із того, що свобода є природним станом та будь-яке обмеження їі повинно бути виправдано серйозним публічним інтересом. Обмеження волі повинно застосовуватися лише тоді, коли інші заходи не діють, воно повинно бути винятком, а не правилом. Через те активне впровадження застави в практику допоможе позбавитися багатьох проблем кримінальної системи та зберегти особисту свободу людини [13, с. 40].

Так у рішенні Європейського Суду зправ людини (далі - ССПЛ) «Летельє проти Франщіi» від 26.06.1991 р. Суд зазначив, що коли єдиною підставою продовження строку тримання під вартою є побоювання, що обвинувачений зникне і таким чином уникатиме потім явки на судовий процес, його належить звільнити, якщо він у змозі забезпечити достатні гарантії такої явки, наприклад, через внесення застави [19, с. 106].

У рішенні ССПЛу справі «Мангурас проти Іспанії від 28.09.2010 р., посилаючись на п. 3 ст. 5 Конвенщіїпро захист прав людини та основоположних свобод, заявник стверджував, що сума застави у його справі $є$ необгрунтовано високою та не враховувала конкретні умови його особистого життя. ССПЛ підтвердив, що внесення застави може вимагатися лише за наявності законних підстав для затримання особи, а також те, що уповноваженні органи влади повинні приділити визначенню суми застави стільки ж уваги, скільки і вирішенню питання про необхідність подалышого тримання обвинуваченого під вартою. Є обгрунтованим врахування й суми збитків, у заподіянні яких ця особа обвинувачується. Заявника було позбавлено волі на 83 дні і звільнено після надання сплати застави в сумі 3 мільйони євро [21, с. 121]. Зміст зазначеного рішення 
ЄСПЛ частково відображено в ч. 5 ст. 182 КП К України, де надається можливість слідчому суду або судді при вчиненні тяжкого або особливо тяжкого злочину може перевищувати 80 розмірів мінімальної заробітної плати при вчиненні тяжкого злочину або перевищувати 300 розмірів мінімальної заробітної плати при вчиненні особливо тяжкого злочину. Однак при вчиненні нетяжких злочинів розмір застави є фіксованим, що не відповідає змісту рішення ЄСПЛ «Мангурас проти Іспанії» від 28.09.2010 р. У зв' язку з цим, враховуючи рішення ЄСПЛ «Мангурас проти Іспанії», пропонуємо, щоб за злочини будь-якого ступеня тяжкості суд мав можливість збільшувати розмір застави.

О. В. Верхогляд-Герасименко обгрунтовано вважає, що з питанням про підстави застосування грошового стягнення тісно пов' язане інше, не менш важливе питання щодо порядку їх застосування [1, с. 121]. При визначенні розміру грошового стягнення слід враховувати не тільки майнове й сімейне становище особи, рівень ї̈ доходів, але й характер вчиненого нею порушення, конкретні наслідки, які настали в результаті невиконання взятих на себе обов'язків [1, с. 123]. Слід погодитися також із пропозищією доповнення ч. 1 ст. 335 і ч. 9 ст. 335 КПК України положенням про вирішення в резолютивній частині обвинувального вироку питання про повернення застави заставодавцю з метою забезпечення майнових прав заставодавця [1, с. 180], оскільки в разі її прийняття така пропозищія дозволить урегулювати питання про повернення застави заставодавцю на законодавчому рівні.

О. П. Кучинська та Н. О. Іверук вважають, що необхідною є законодавча регламентація правового статусу заставодавця як учасника кримінального провадження, розширення переліку його прав та розробка механізму реалізації обов'язків шляхом внесення змін не лише до КП УК України, але й до Закону Украӥни «Про забезпечення безпеки осіб, які беруть участь у кримінальному судочинстві», зокрема внесення заставодавця до переліку осіб, які потребують захисту [15, с. 55]. 3 огляду на ст. 3 Конституції Украӥни та ст. 8 КПК Украӥни, захист прав заставодавців шляхом внесення змін до Закону України «Про забезпечення безпеки осіб, які беруть участь у кримінальному судочинстві» шляхом внесення заставодавця до переліку осіб, які потребують захисту, $\epsilon$ доцільним.

Через те що суспільна небезпечність злочинів вища, ніж кримінальних проступків (але притім до суб'єктів злочинів можливе застосування застави, а для кримінальних проступків поки що ні), враховуючи мету запобіжних заходів (ч. 1 ст. 176 КПК України) та правову природу положень ст. 182 КПК України «Застава», невиправданою видається заборона застосування запобіжного заходу у виді застави під час досудового розслідування кримінальних проступків. Тому в чинній редакції ст. 299 КПК України доцільно змінити фразу «...домашнього арешту, застави або тримання під вартою» на «домашнього арешту або тримання під вартою». На наш погляд, враховуючи викладене, доцільно сформулювати зміст ст. 299 КПК України таким чином: «під час досудового розслідування кримінальних проступків не допускається застосування запобіжних заходів у виді домашнъого арешту або тримання під вартою». Також для дієвого застосування застави слід доповнити ч.5 ст. 182 КПК України вказівкою на можливість застосування застави при вчиненні кримінальних проступків [22, с. 126]. 
М. М. Стефанчук, Н. О. Іверук вказали про необхідність з'ясування законності походження коштів як предмета застави, обгрунтованості судового рішення при визначенні розміру застави, який перевищує встановлені КТК України межі [34, с. 66]. До питання щодо законності походження коштів заставодавця також звертався С. М. Каплін: як автор проекту Закону України «Про внесення змін до статті 182 Кримінального процесуального кодексу України (щодо підтвердження легальності походження коштів, внесених у якості застави)» (реєстр. № 2086 від 10.02.2015), метою законопроекту він вказав удосконалення механізму застосування запобіжного заходу в кримінальному провадженні у вигляді застави, зокрема, щодо підтвердження легальності походження внесених коштів. Для досягнення цієї мети ним пропонується запровадити обов' язкове документальне підтвердження підозрюваним, обвинуваченим або заставодавцем легальності походження коштів, унесених як застава. Зокрема, підозрюваний, обвинувачений, заставодавець у разі ухвалення цього законопроекту будуть зобов' язані надати слідчому судиі, суду лист-клопотання, у якому зазначатимуться джерела походження коштів, унесених як застава, та надати документи, які підтверджують їх легальність [27].

У Висновку Правового управління Верховного Суду України на проект Закону України про внесення змін до статті 182 Кримінального процесуального кодексу України (щодо підтвердження легальності походження коштів, унесених у якості застави) зазначено, що вказаний законопроект потребує доопрацювання з огляду на те, що запропоновані зміни до статті 182 КТК України потребують невідкладного створення дієвого механізму, завдяки якому слідчий суддя, суд мали би змогу якісно перевірити достовірність поданих даних щодо легальності походження коштів, унесених як застава. Інакше зазначені законодавчі новели не матимуть перспективи їх практичного застосування. Доцільно також увести норму, яка передбачала б звернення застави в дохід держави в порядку, установленому частиною восьмою статті 182 КПК України, у разі відсутності належного підтвердження легальності джерел походження заставлених коштів [28].

Важливим є дослідження судової практики (ухвал щодо застави) з метою врахування та недопущення в майбутньому помилок у правозастосуванні.

Більшість судів у вироках указують лише суму застави в національній грошовій одинищі [40-45], що суперечить ст. 182 КПК України.

Окремі суди у вироках вказують не лише кількість прожиткового мінімуму для працездатних осіб, але й еквівалент у національній грошовій одинищі (вирок Білоцерківського міськрайонного суду Київської області від 20.01.2020 р., справа № 357/2363/19; вироки Сєвєродонецього міського суду Луганської області від 21.12 .2019 р., справа № 428/13047/19 та від 15.04.2020 р., справа № 428/3147/20; вирок Сихівського районного суду м. Львова від 29.01.2020 р., справа № 464/6567/19) [36-39].

Як бачимо, не всі суди вказують і кількість прожиткових мінімумів для працездатних осіб, і відповідний еквівалент у національній грошовій одинищі. Водночас, така практика, на наш погляд, заслуговує на підтримку, оскільки відповідає змісту ст. 182 КПК України та надає можливість розібратися в сумі застави, а також не потребує додаткових правових роз'яснень.

Висновки. Отже, застава в кримінальному процесуальному законодавстві України - неізоляційний, психолого-примусовий запобіжний захід. 
Якістю кримінального процесуального законодавства ми вважаємо оцінну категорію, яка означає здатність КПК України та інших джерел кримінального процесуального законодавства України виконати свої завдання в кримінальному провадженні, задовольнити соціально-правові очікування від їх реалізації.

На підставі викладеного вбачається, що ст. 182 КПК України «Застава» потребує вдосконалення шляхом усунення логіко-лінгвістичного дефекту. Тож пропонуємо п. 3 ч. 5 ст. 182 КПК України викласти в такій редакції: «...щодо особи, підозрюваної чи обвинуваченої у вчиненні необережного особливо тяжкого злочину, - від вісімдесяти до трьохсот розмірів прожиткового мінімуму для працездатних осіб».

У ч. 5 ст. 182 КПК України надається можливість слідчому суду або судді збільшити розмір застави при вчиненні тяжкого або особливо тяжкого злочину. Водночас, при вчиненні нетяжких злочинів розмір застави є фіксованим, що частково не відповідає змісту рішення ССПЛ «Мангурас проти Іспаніï від 28.09.2010 р., тому що розмір заподіяної шкоди може бути різним. Це потребує відображення в ч. 5 ст. 182 КПК України шляхом надання можливості слідчому суду або судді збільшити розмір застави при вчиненні нетяжких злочинів.

У чинній редакції ст. 299 КІК України доцільним видається надання можливості застосування застави при вчиненні кримінальних проступків. На наш погляд, враховуючи викладене, доцільн сформулювати зміст ч. 1 ст. 299 КПК України таким чином: «Під час досудового розслідування кримінальних проступків не допускається застосування запобіжних заходів у виді домашнъого арешту або тримання під вартою». Для дієвого застосування застави, у разі внесення змін у ч.1 ст. 299 КПК України, слід також доповнити ч.5 ст. 182 КП ІК України вказівкою на можливість застосування застави при вчиненні кримінальних проступків.

Погоджуємося 3 пропозицією доповнення ч. 1 ст. 335 і ч. 9 ст. 335 КПК України положенням про вирішення в резолютивній частині обвинувального вироку питання про повернення застави заставодавцю з метою забезпечення майнових прав заставодавця [1, с. 180], оскільки у разі їі прийняття буде врегульоване питання про повернення застави заставодавцю на законодавчому рівні.

Удосконалення якості кримінального процесуального законодавства України щодо порядку застосування застави має, на наш погляд, полягати в наданні можливості внесення застави в негрошовому виді, що відповідає такій загальній засаді кримінального провадження, як верховенство права.

Тож , на наш погляд, доцільним видається подальше удосконалення якості норм КТК України щодо інших запобіжних заходів.

\section{Використані джерела:}

1. Верхогляд-Герасименко О. В. Забезпечення майнових прав особи при застосуванні заходів кримінально-процесуального примусу: монографія. Харків : Юрайт, 2012. 216 с.

2. Андроник Н. А. Залог, домашний арест: проблемы правового регулирования. Becmник ВИМВД России. 2014. № 4. С. 69-75.

3. Вишньова Д. В. Судовий контроль під час застосування застави у кримінальному процесі. Право і суспільство. 2015. № 5-2. С. 194-200.

4. Дрозд В. Ю. Проблемні аспекти застосування застави як одного з видів запобіжних заходів, не пов'язаних з обмеженням волі особи. Вісник Луганського державного університету внутрішніх справ імені Е. О. Дідоренка. № 1. 2016. С. 72-80. 
5. Ільченко О. В. Актуальні питання щодо застосування застави у кримінальному судочинстві. Юридичний науковий електронний журнал. 2016. Вип. 3. С. 150-152.

6. Лобойко Л. М., Банчук О. А. Кримінальний процес: Навч. посібник. Киӥв: Ваіте, 2014. 280 c.

7. Глинська Н. В. Концептуальні засади визначення та забезпечення стандартів доброякісності кримінальних процесуальних рішень: монографія. Київ: Істина. 2014. 588 с.

8. Письменний Д. П. Удосконалення кримінального процесуального законодавства України: стан і перспективи. Юридичнии часопис національної академії внутрішніх справ. № 2 . 2013. С. 38-47.

9. Лобойко Л. М. Якість кримінального процесуального закону - гарантія його ефективної реалізації. Актуальні проблеми удосконалення кримінального процесуального законодавства: матеріали Всеукр. наук.-практ. конф., присвяч. до 70-річчя д.ю.Н., проф. Ю.П. Аленіна (м. Одеса, 21 квітня 2017 р.). Одеса: Юрид. літ., 2017. С. 30-31.

10. Петров О. Актуальні питання застосування застави як різновиду запобіжного заходу за чинним кримінальним процесуальним кодексом України. Науковий вісник Міжнародного гуманітарного університету. Серія Юриспруденциія. 2017. Вип. 25. С. 110-112.

11. Теоретичні основи забезпеченн якості кримінального законодавства та правозастосовчої діяльності у сфері боротьби зі злочинністю в Україні: монографія / за заг. ред. В. І. Борисова, В. С. Зеленецького. Харків: Право, 2011.344 с.

12. Попелюшко В. О. Запобіжні заходи в новому КТКК України: поняття, мета, підстави, порядок та суб'єкти застосування. Адвокат. 2012. № 9. С. 4-6.

13. Андроник Н. А. Сравнительный анализ применения залога в России и зарубежных странах. Вестник Уральского института экономики, управления и права. 2014. № 4. С. 33-41.

14. Карпенко М. О., Туманянщ А. Р. Деякі проблеми прав і забезпечення інтересів заставодавців і поручителів у кримінальному провадженні. Науковий Вісник Херсонського державного університету. 2016. Вип. 4, т. 2. С. 90-93.

15. Кучинська О. П., Іверук Н. О. Правовий статус заставодавця як учасника кримінального провадження: окремі аспекти законодавчого врегулювання та правозастосовної практики. Вісник кримінального судочинства. 2018. № 2. С. 49-57.

16. Музиченко Т. О. Питання вдосконалення правового регулювання обрання та застосування запобіжного заходу у вигляді застави на стадії досудового розслідування. Вісник кримінального судочинства. 2017. №3. С. 205-215.

17. Січко В. О. Обрання, скасування або зміна запобіжного заходу у судовому провадженні: дис. ... канд. юрид. наук.: спец. 12.00 .09 - «Кримінальний процес та криміналістика; судова експертиза; оперативно-розшукова діяльність». Харків: Нащіональний юрид. ун-тет імені Ярослава мудрого. 2019. 276 с.

18. Тищенко О. І. Окремі аспекти застосування запобіжного заходу у вигляді застави (за матеріалами судової практики). Юридичний науковий електронний журнал. 2016. № 2. С. 140-141.

19. МакбрайдД. Свропейська Конвенщія зправ людини та кримінальнийпроцес. Київ: K.I.C., 2010.576 c.

20. Крайнюк В. Г. Застава як запобіжний захід в кримінальному судочинстві. Учёные записки Таврического национального университета имени В.И. Вернадского. Серия «Юридические науки». Том 26 (65). 2013. № 1. С. 401-407.

21. Рішення Європейського Суду з прав людини у справі «Мангурас проти Іспанії» (Mangourasv.Spain) від28 вересня 2010p.URL:http://hrlib.kz/wp-content/uploads/2016/08/2010\%D0\%9C\%D0\%B0\%D0\%BD\%D0\%B3\%D1\%83\%D1\%80\%D0\%B0\%D1\%81-\%D0\%BF\%D1\%80\% D0\%BE\%D1\%82\%D0\%B8\%D0\%B2-\%D0\%98\%D1381\%D0\%BF\%D0\%B0\%D0\%BD\%D0\%B8\% D0\%B8.pdf. 
22. Крайник Г. С., Дунаєва Т. С. Актуальні питання удосконалення запобіжних заходів у виді особистої поруки та застави. Актуальні питання теорії та практики в галузі права, освіти, соијіальних та поведінкових наук - 2020: матеріали міжнар. наук.-практ. конф. (м. Чернігів, 2324 квіт. 2020 р.): у двох томах. Т. 2 / гол. ред.: О. М. Тогочинський. Академія Державної пенітенціарної служби. Чернігів: Академія ДПтС, 2020.382 с. С. 122-126.

23. Кримінальний процес : підручник / Ю.М.Грошевий, В. Я. Тацій, А. Р. Туманянщ та ін.; за ред. В. Я. Тація, Ю. М. Грошевого, О. В. Капшіної, О. Г. Шило. Харків: Право, 2013. 824 с.

24. Порядок внесення коштів на спеціальний рахунок у разі застосування застави як запобіжного заходу: затверджений постановою Кабінету Міністрів України від 11 січня 2012 p. № 15. URL:http:/ / zakon5.rada.gov.ua/laws/show/15-2012-H.

25. Про практику застосування судами застави як запобіжного заходу: постанова Пленуму ВСУ № 6 від 26.03.1999 p. URL:https:/ /zakon.rada.gov.ua/laws/show/v0006700-99. Дата звернення 04.05.2020.

26. Бондаренко О. М. Зарубіжний досвід застосування деяких запобіжних заходів. Держава і право. Юридичні і політичні науки. 2013. Вип. 62. С. 305-310. URL:http://nbuv.gov. ua/UJRN/ dip_2013_62_50.

27. Про внесення змін до статті 182 Кримінального процесуального кодексу України (щодо підтвердження легальності походження коштів, внесених у якості застави): Проект Закону України, внесеного на розгляд Верховної Ради України народним депутатом України Капліним С. М. (реєстр. № 2086 від 10.02.2015).

28. Висновок Правового управління Верховного Суду України на проект Закону України про внесення змін до статті 182 Кримінального процесуального кодексу Украӥни (щодо підтвердження легальності походження коштів, внесених у якості застави). URL:http:// www.viaduk.net/clients/vsu/vsu.nsf/(print)/63545850ABFBA597C2257E1F00499BA7.

29. Про деякі питання порядку застосування запобіжних заходів під час досудового розслідування та судового провадження відповідно до Кримінального процесуального кодексу України: Лист Вищого спеціалізованого суду України з розгляду цивільних та кримінальних справ № 511-550/0/4-13 від 04.04.2013. URL:https://zakon. rada.gov. ua/laws/show/ v0511740-13\#Text.

30. Садова Т. Застава в контексті англо-американської правової традищії. Підириємницmbo, господарство і право. 2008. Вип. 7. С. 141-144.

31. Уваров В. Г. Інститут запобіжних заходів за новим КПК Украӥни в контексті міжнародних стандартів. Право і суспільство. 2012. № 2. С. 294-297.

32. Фаринник В. Особливості застосування запобіжних заходів у кримінальному провадженні. Юридичний Вісник України. 2012. 22-28 верес. (№38). С. 4.

33. Shilo O. The issue of adaptation of the criminal procedural law of Ukraine to the law of the European Union. Щорічник українського права. Харків: Право, 2017. № 9. С. 319-329.

34. Стефанчук М. М., Іверук Н. О. Проблеми визначення розміру застави при обранні запобіжного заходу за законодавством України та країн англо-американської правової сім’ї: порівняльно-правовий аналіз. Вісник кримінального судочинства. № 4. 2019. С. 58-68.

35. Про внесення змін до деяких законодавчих актів Українищодо спрощення досудового розслідування окремих категорій кримінальних правопорушень: Закон України від 22 листопада 2018 р. № 2617-VIII. Відомості Верховної Ради. 2019. №17. Ст. 71.

36. Вирок Білоцерківського міськрайонного суду Київської області від 20.01 .2020 р. Справа №357/2363/19. URL:http:/ / www.reyestr.court.gov.ua/Review/87028722.

37. Вирок Северодонецього міського суду Луганської області від 21.12.2019 р. Справа № 428/13047/19. URL:http://www.reyestr.court.gov.ua/Review/86713669. 
38. Вирок Сєвєродонецького міського суду Луганської області від 15.04 .2020 р. Справа № 428/3147/20. URL:http://www.reyestr.court.gov.ua/Review/88828148.

39. Вирок Сихівського районного суду м. Львова від 29.01.2020 р. Справа № 464/6567/19. URL:http:// www.reyestr.court.gov.ua/Review/87278800.

40. Вирок Жовтневого районного суду м. Запоріжжя від 27.05 .2020 р. Справа № 331/ 4171/19. URL:http://www.reyestr.court.gov.ua/Review/89455589.

41. Вирок Новозаводського районного суду міста Чернігова від 18.04 .2019 р. Справа№751/1948/19. URL:http://www.reyestr.court.gov.ua/Review/81254963.

42. Вирок Солом янського районного суду м. Києва від 21.11.2019 р. Справа № 760/ 31969/19. URL:http://www.reyestr.court.gov.ua/Review/85806269.

43. Вирок Заводський районний суд м. Запоріжжя від 21.11.2019 р. Справа №332/ 3633/19. URL:http://www.reyestr.court.gov.ua/Review/85785356.

44. Вирок Демидівського районного суду Рівненської області від 02.03 .2020 р. Справа № 559/200/20. URL:http://www.reyestr.court.gov.ua/Review/87925251.

45. Вирок Кіровського районного суду м. Кіровограда від 04.06.2020 р. Справа № 404/ 1263/20. URL:http://www.reyestr.court.gov.ua/Review/89636669.

\section{References:}

1. Verkhohlyad-Herasymenko, O. V. (2012) Zabezpechennya maynovykh prav osoby pry zastosuvanni zakhodiv kryminal'no-protsesual'noho prymusu: monohrafiya. Kharkiv: Yurayt. [in Ukrainian].

2. Andronyk, N. A. (2014) Zaloh, domashnyy arest: problemy pravovoho rehulyrovanyya. Vestnyk VY MVD Rossyy- Bulletin of the VI Ministry of Internal Affairs of Russia, 4, 69-75. [in Russian].

3. Vyshn'ova, D. V. (2015) Sudovyy kontrol' pid chas zastosuvannya zastavy u kryminal'nomu protsesi. Pravo i suspil'stvo - Law and society, 5-2, 194-200. [in Ukrainian].

4. Drozd, V. YU. (2016) Problemni aspekty zastosuvannya zastavy yak odnoho z vydiv zapobizhnykh zakhodiv, ne pov' yazanykh z obmezhennyam voli osoby. Visnyk Luhans'koho derzhavnoho universytetu vnutrishnikh sprav imeni E. Didorenka - Bulletin of Luhansk State University of Internal Affairs named after E. Didorenko, 1, 72-80. [in Ukrainian].

5. Il'chenko, O. V. (2016) Aktual'ni pytannya shchodo zastosuvannya zastavy u kryminal'nomu sudochynstvi. Yurydychnyy naukooyy elektronnyy zhurnal - Legal scientific electronic journal, issue 3, 150-152. [in Ukrainian].

6. Loboyko, L. M., Banchuk, O. A. (2014) Kryminal'nyy protses: Navch. posibnyk. Kyyiv: Vaite. [in Ukrainian].

7. Hlyns'ka, N. V. (2014) Kontseptual'ni zasady vyznachennya ta zabezpechennya standartiv dobroyakisnosti kryminal'nykh protsesual'nykh rishen: monohrafiya. Kyyiv: Istyna. [in Ukrainian].

8. Pys'mennyy, D. P. (2013) Udoskonalennya kryminal'noho protsesual'noho zakonodavstva Ukrayiny: stan i perspektyvy. Yurydychnyy chasopys natsional'noyi akademiyi vnutrishnikh sprav - Legal Journal of the National Academy of Internal Affairs, 2, 38-47. [in Ukrainian].

9. Loboyko, L. M. (2017) Yakist' kryminal'noho protsesual'noho zakonu - harantiya yoho efektyvnoyi realizatsiyi. Aktual'ni problemy udoskonalennya kryminal'noho protsesual'noho zakonodavstva: materialy Vseukr. nauk. prakt. konf., prysoyach. do 70-richchya d.yu.n., prof. YU. P. Alenina (m. Odesa, 21 kvitnya 2017 r.). - Actual problems of improvement of the criminal procedural legislation: materials All-Ukrainian. Science. practice. conf., dedicated. to the 70th anniversary of Dr., Prof. Yu. P. Alenin (Odessa, April 21, 2017). Odesa: Yuryd. lit., 30-31. [in Ukrainian].

10. Petrov, O. (2017) Aktual'ni pytannya zastosuvannya zastavy yak riznovydu zapobizhnoho zakhodu za chynnym kryminal'nym protsesual'nym kodeksom Ukrayiny. Naukoryy 
visnyk Mizhnarodnoho humanitarnoho universytetu. Seriya Yurysprudentsiya - Науковий Вісник Міжнародного гуманітарного університету. Серія Юриспрудениія, issuе 25, 110-112. [in Ukrainian].

11. Teoretychni osnovy zabezpechenn yakosti kryminal'noho zakonodavstva ta pravozastosovchoyi diyal'nosti u sferi borot'by zi zlochynnistyu v Ukrayini: monohrafiya. (2011) V. I. Borysov, \& V.S. Zelenets'kiy. Kharkiv: Pravo. [in Ukrainian].

12. Popelyushko, V. O. (2012) Zapobizhni zakhody v novomu KPK Ukrayiny: ponyattya, meta, pidstavy, poryadok ta sub'yekty zastosuvannya. Advokat - Lawyer, 9, 4-6. [in Ukrainian].

13. Andronyk, N. A. (2014) Sravnytel'nyy analyz prymenenyya zaloha v Rossyy y zarubezhnykh stranakh. Vestnyk Ural'skoho ynstytuta ékonomyky, upravlenyya y prava - Bulletin of the Ural Institute of Economics, Management and Law, 4, 33-41. [in Russian].

14. Karpenko, M. O., Tumanyants, A. R. (2016) Deyaki problemy prav i zabezpechennya interesiv zastavodavtsiv i poruchyteliv u kryminal'nomu provadzhenni. Naukooyy visnyk Khersons'koho derzhavnoho universytetu - Scientific Bulletin of Kherson State University, issue 4, vol. 2, 90-93. [in Ukrainian].

15. Kuchyns'ka, O. P., Iveruk, N. O. (2018) Pravovyy status zastavodavtsya yak uchasnyka kryminal'noho provadzhennya: okremi aspekty zakonodavchoho vrehulyuvannya ta pravozastosovnoyi praktyky. Visnyk kryminal'noho sudochynstva - Bulletin of criminal proceedings, 2, 49-57. [in Ukrainian].

16. Muzychen,ko T. O. (2017) Pytannya vdoskonalennya pravovoho rehulyuvannya obrannya ta zastosuvannya zapobizhnoho zakhodu u vyhlyadi zastavy na stadiyi dosudovoho rozsliduvannya. Visnyk kryminal'noho sudochynstva - Bulletin of criminal proceedings, 3, 205-215. [in Ukrainian].

17. Sichko, V. O. (2019) Obrannya, skasuvannya abo zmina zapobizhnoho zakhodu u sudovomu provadzhenni. Candidate's of thesis. Kharkiv: Natsional'nyy yuryd. un-tet imeni Yaroslava mudroho. [in Ukrainian].

18. Tyshchenko, O. I. (2016) Okremi aspekty zastosuvannya zapobizhnoho zakhodu u vyhlyadi zastavy (za materialamy sudovoyi praktyky). Yurydychnyy naukoryy elektronnyy zhurnal Legal scientific electronic journal, 2, 140-141. [in Ukrainian].

19. Makbrayd, D. (2010) Yevropeys'ka Konventsiya z prav lyudyny ta kryminal'nyy protses. Kyiv: K.I.S. [in Ukrainian].

20. Kraynyuk, V.H. (2013) Zastava yak zapobizhnyy zakhid v kryminal'nomu sudochynstvi. Uchenye zapysky Taurycheskoho natsyonal'noho unyversyteta ymeny V.Y. Vernadskoho. Seryya "Yurydycheskye nauky» - Scientific notes of the Tauride National University named after VI Vernadsky. Legal Sciences Series, vol. 26 (65), 1, 401-407. [in Ukrainian].

21. Rishennya Yevropeys'koho Sudu z prav lyudyny u spravi «Manhuras proty Ispaniyi» (Mangouras v. Spain) vid 28 veresnya 2010 roku. (2010) N. p. URL:http:// hrlib.kz/wp-content/uploads/2016/08/2010-\%D0\%9C\%D0\%B0\%D0\%BD\%D0\%B3\% D1\%83\%D1\%80\%D0\%B0\%D1\%81-\%D0\%BF\%D1\%80\%D0\%BE\%D1\%82\%D0\%B8\%D0\% B2-\%D0\%98\%D1381\%D0\%BF\%D0\%B0\%D0 \%BD\%D0\%B8\%D0\%B8.pdf. [in Ukrainian].

22. Kraynyk, H. S., Dunaieva, T. Ye. (2020) Aktual'ni pytannya udoskonalennya zapobizhnykh zakhodiv u vydi osobystoyi poruky ta zastavy. Aktual'ni pytannya teoriyi ta praktyky vhaluzi prava, osvity, sotsial'nykh ta povedinkovykh nauk-2020: materialy mizhnar. nauk.-prakt. konf. (m. Chernihiv, 23-24 kvit. 2020 r.): u dvokh tomakh.- Current issues of theory and practice in the field of law, education, social and behavioral sciences - 2020: materials intern. scientific-practical conf. (Chernihiv, April 23-24, 2020). Vol. 1-2; Vol. 2. O. M. Tohochyns'kyy (Ed.). Akademiya Derzhavnoyi penitentsiarnoyi sluzhby. Chernihiv: Akademiya DPtS, 122-126. [in Ukrainian]. 
23. Kryminal'nyy protses: pidruchnyk. (2013) YU. M. Hroshevyy, V. YA. Tatsiy, A. R. Tumanyants (Eds.) et al.; V. YA. Tatsii, YU. M. Hroshevoi, O. V. Kaplina, O. H. Shylo (Eds.). Kharkiv: Pravo. [in Ukrainian].

24. Poryadok vnesennya koshtiv na spetsial'nyy rakhunok u razi zastosuvannya zastavy yak zapobizhnoho zakhodu: zatverdzhenyy postanovoyu Kabinetu Ministriv Ukrayiny vid 11 sichnya 2012 r. № 15. (2020) N. p. URL:http:/ / zakon5.rada.gov.ua/laws/show/15-2012-H. [in Ukrainian].

25. Pro praktyku zastosuvannya sudamy zastavy yak zapobizhnoho zakhodu: postanova Plenumu VSU № 6 vid 26.03.1999. (1999) N. p. URL:https://zakon.rada.gov. ua/laws/show/ v0006700-99. [in Ukrainian].

26. Bondarenko, O. M. (2013) Zarubizhnyy dosvid zastosuvannya deyakykh zapobizhnykh zakhodiv. Derzhava i pravo. Yurydychni i politychni nauky - State and law. Legal and political sciences, issue 62, 305-310. URL:http://nbuv.gov.ua/UJRN/dip_2013_62_50. [in Ukrainian].

27. Pro vnesennya zmin do statti 182 Kryminal'noho protsesual'noho kodeksu Ukrayiny (shchodo pidtverdzhennya lehal'nosti pokhodzhennya koshtiv, vnesenykh u yakosti zastavy): Proekt Zakonu Ukrayiny, vnesenoho na roz hlyad Verkhovnoyi Rady Ukrayiny narodnym deputatom Ukrayiny Kaplinym S. M. (reyestr. № 2086 vid 10.02.2015). N. d. N. p. [in Ukrainian].

28. Vysnovok Pravovoho upravlinnya Verkhovnoho Sudu Ukrayiny na proekt Zakonu Ukrayiny pro vnesennya zmin do statti 182 Kryminal'noho protsesual'noho kodeksu Ukrayiny (shchodo pidtverdzhennya lehal'nosti pokhodzhennya koshtiv, vnesenykh u yakosti zastavy). N. d. N. p. URL:http://www.viaduk.net/clients/vsu/vsu.nsf/(print)/63545850ABFBA597C2257E1F00499BA 7. [in Ukrainian].

29. Pro deyaki pytannya poryadku zastosuvannya zapobizhnykh zakhodiv pid chas dosudovoho rozsliduvannya ta sudovoho provadzhennya vidpovidno do Kryminal'noho protsesual'noho kodeksu Ukrayiny: Lyst Vyshchoho spetsializovanoho sudu Ukrayiny z roz hlyadu tsyvil'nykh ta kryminal'nykh sprav № 511-550/0/4-13 vid 04.04.2013. (2013) N. p. URL:https:/ / zakon.rada.gov.ua/laws/show/v0511740-13\#Text. [in Ukrainian].

30. Sadova, T. (2008) Zastava v konteksti anhlo-amerykans'koyi pravovoyi tradytsiyi. Pidpryyemnytstvo, hospodarstvo i parvo - Entrepreneurship, economy and law, issue 7, 141-144. [in Ukrainian].

31. Uvarov, V. H. (2012) Instytut zapobizhnykh zakhodiv za novym KPK Ukrayiny v konteksti mizhnarodnykh standartiv. Pravo i suspil'stvo - Society and Law, 2, 294-297. [in Ukrainian].

32. Farynnyk, V. (2012) Osoblyvosti zastosuvannya zapobizhnykh zakhodiv u kryminal'nomu provadzhenni. Yurydychnyy visnyk Ukrayiny - Legal Bulletin of Ukraine, 38, 4. [in Ukrainian].

33. Shilo, O. (2017) The issue of adaptation of the criminal procedural law of Ukraine to the law of the European Union. Shchorichnyk ukrayins'koho prava - Yearbook of Ukrainian law, 9, 319-329. Kharkiv: Pravo. [in Ukrainian].

34. Stefanchuk, M. M., Iveruk, N. O. (2019) Problemy vyznachennya rozmiru zastavy pry obranni zapobizhnoho zakhodu za zakonodavstvom Ukrayiny ta krayin anhlo-amerykans'koyi pravovoyi sim'yi: porivnyal'nopravovyy analiz. Visnyk kryminal'noho sudochynstva - Bulletin of criminal proceedings, 4, 58-68. [in Ukrainian].

35. Pro vnesennya zmin do deyakykh zakonodavchykh aktiv Ukrayiny shchodo sproshchennya dosudovoho rozsliduvannya okremykh katehoriy kryminal'nykh pravoporushen': Zakon Ukrayiny vid 22 lystopada 2018 r. № 2617-VIII. (2018) Vidomosti Verkhoonoyi Rady - Information of the Verkhorna Rada, 17, art. 71. [in Ukrainian].

36. Vyrok Bilotserkivs'koho mis'krayonnoho sudu Kyyivs`koyi oblasti vid 20.01.2020 r. Sprava №357/2363/19. (2020) N. p. URL:http:/ / www.reyestr.court.gov.ua/Review/87028722. [in Ukrainian]. 
37. Vyrok Syevyerodonets`oho mis`koho sudu Luhans`koyi oblasti vid 21.12.2019 r. Sprava № 428/13047/19. (2019) N. p. URL:http://www.reyestr.court.gov.ua/Review/86713669. [in Ukrainian].

38. Vyrok Syevyerodonets`koho mis`koho sudu Luhans ‘koyi oblasti vid 15.04 .2020 r. Sprava № 428/3147/20. (2020) N. p. URL: http://www.reyestr.court.gov.ua/Review/88828148. [in Ukrainian].

39. Vyrok Sykhivs koho rayonnoho sudu m. L`vova vid 29.01.2020 r. Sprava № 464/6567/19. (2020) N. p. URL:http://www.reyestr.court.gov.ua/Review/87278800. [in Ukrainian].

40. Vyrok Zhovtnevoho rayonnoho sudu m. Zaporizhzhya vid 27.05.2020 r. Sprava № 331/4171/19.(2020)N.p.URL:http://www.reyestr.court.gov.ua/Review/89455589. [inUkrainian].

41. Vyrok Novozavods'koho rayonnoho sudu mista Chernihova vid 18 kvitnya 2019 r. SpravaNo751/1948/19. (2019) N. p. URL:http://www.reyestr.court.gov.ua/Review/81254963. [in Ukrainian].

42. Vyrok Solom 'yans'koho rayonnoho sudu m. Kyyeva vid 21.11.2019 r. Sprava № 760/31969/19. (2019) N. p. URL:http://www.reyestr.court.gov.ua/Review/85806269. [in Ukrainian].

43. VyrokZavods'kyy rayonnyy sud m. Zaporizhzhya vid 21.11.2019r. Sprava № 332/3633/19. (2019) N.p. URL:http://www.reyestr.court.gov.ua/Review/85785356. [in Ukrainian].

44. Vyrok Demydivs'koho rayonnoho sudu Rivnens'koyi oblasti vid 02.03 .2020 r. Sprava № 559/200/20. (2020) N.p. URL:http://www.reyestr.court.gov.ua/Review/87925251. [in Ukrainian].

45. Vyrok Kirovs'koho rayonnoho sudu m. Kirovohrada vid 04.06.2020 r. Sprava № 404/1263/20.(2020)N.p.URL:http:/ /www.reyestr.court.gov.ua/Review/89636669. [inUkrainian].

Стаття надійшла до редколегіï 30.08.2020

Крайник Г. С., кандидат юридических наук, доцент кафедры уголовно-правовых дисциплин и административного права Харьковского университета (г. Харьков, Украина)

Дунаева Т. Е., кандидат юридических наук, научный сотрудник Научно-исследовательского института изучения проблем преступности имени академика В. В. Сташиса НАПрН Украины (г. Харьков, Украина)

\section{КАЧЕСТВО УГОЛОВНОГО ПРОЦЕССУАЛЬНОГО ЗАКОНОДАТЕЛЬСТВА УКРАИНЫ, РЕГУЛИРУЮЩЕГО ОСНОВАНИЯ И ПОРЯДОК ПРИМЕНЕНИЯ ЗАЛОГА}

В статье исследованы актуальные вопросы залога как меры пресечения. Предложено законодательные изменения в ст. 182 Уголовного процессуального кодекса Украины, которые надлежащим образом урегулируют вопросы применения залога в Украине и устранят существующие недостатки. Обоснована необходимость внесения изменений в указанную статью и внедрения залога в неденежной форме.

Действующую редакцию ст. 299 Уголовного процессуального кодекса Украины предложено усовершенствовать путем предоставления возможности применения залога при совершении уголовных проступков. 
Целесообразно дополнить ч. 1 ст. 335 и ч. 9 ст. 335 Уголовного процессуального кодекса Украины положением о решении в резолютивной части обвинительного приговора вопроса о возврате залога залогодателю.

Внедрение указанных предложений будет способствовать усовершенствованию качества уголовного процессуального законодательства Украины относительно залога как меры пресечения.

Ключевые слова: меры пресечения, залог, качество уголовного процессуального законодательства Украины, уголовное процессуальное право Украины; уголовное судопроизводство.

Krainyk H.,

Ph.D in Law,

Associate Professor of the Department of Criminal Law disciplines and Administrative Law of Kharkiv University

(Kharkiv, Ukraine)

Dunaieva T.,

Ph.D in Law,

Scientific researcher of Academician Stashis Scientific Research

Institute for the Study of Crime Problems

of the National Academy of Law Sciences of Ukraine

(Kharkiv, Ukraine)

\section{QUALITY OF CRIMINAL PROCEDURAL LEGISLATION OF UKRAINE, WHICH REGULATES THE GROUNDS AND PROCEDURE OF APPLICATION OF THE BAIL}

The article examines current issues regarding collateral as a precautionary measure. Legislative changes to Article 182 of the Criminal Procedure Code of Ukraine, which will properly regulate the use of bail in Ukraine and eliminate existing shortcomings.

Article 182 of the Criminal Procedure Code of Ukraine «The bail» needs to be improved. We propose paragraph 3 of part 5 of Article 182 of the Criminal Procedure Code of Ukraine to read as follows: «for a person suspected or accused of committing a negligent particularly serious crime - from eighty to three hundred living wage for able-bodied persons».

When committing crimes of minor or medium gravity, the amount of bail is fixed, which is partly inconsistent with the content of the judgment of the European Court of Human Rights «Manguras v. Spain» of 28.09.2010, because the amount of damage may be different. This needs to be reflected in part 5 of Article 182 of the Criminal Procedure Code of Ukraine by allowing the investigating court or judge to increase the amount of bail for a crime of minor or medium gravity.

In the current edition of Article 299 of the Criminal Procedure Code of Ukraine, it is advisable to amend the provision of the possibility of using a bail in the commission of criminal offenses.

In our opinion, given the above, it is appropriate to formulate the content of Part 1 of Article 299 of the Criminal Procedure Code of Ukraine as follows: «During the pre-trial investigation of criminal offenses, the application of precautionary measures in the form of house arrest or detention is not allowed». For the effective application of collateral, in the case of changes in Part 1 of Article 299 of the Criminal Procedure Code of Ukraine, should also add part 5 of Article 182 of 
the Criminal Procedure Code of Ukraine indicating the possibility of using bail in committing criminal offenses.

We agree with the proposal to supplement part 1 of Article 335 and part 9 of Article 335 of the Criminal Procedure Code of Ukraine, the provision on resolving in the operative part of the conviction the issue of returning the pledge to the mortgagor in order to ensure the property rights of the mortgagor, the timeliness of the return of the pledge was proposed, because in case of its adoption will be settled.

Improving the quality of the criminal procedural legislation of Ukraine on the procedure for applying bail should, in our opinion, be to provide the possibility of bail in accordance with Article 182 of the Criminal Procedure Code of Ukraine in non-monetary form, which corresponds to such a general principle of criminal proceedings as the rule of law.

Keywords: precautionary measures, bail, quality of criminal procedural legislation of Ukraine, criminal procedural law of Ukraine; criminal justice.

DOI: $10.33766 / 2524-0323.91 .117-126$

УДК 343.7

Р. О. Мовчан, кандидат юридичних наук, доцент, доцент кафедри конституційного, міжнародного та кримінального права Донецького національного університету імені Василя Стуса

(м. Вінниця, Україна) e-mail: romanmov1984@gmail.com iD ttps:/ / orcid.org/0000-0003-2074-8895

\section{ПРОБЛЕМИ ЗАСТОСУВАННЯ СТ. 48 КК УКРАЇНИ ЩОДО ОСІБ, ЯКІ ВЧИНИЛИ САМОВІЛЬНЕ ЗАЙНЯТТЯ ЗЕМЕЛЬНОЇ ДІЛЯНКИ ТА САМОВІЛЬНЕ БУДІВНИЦТВО}

У статті розглянуто найбільш дискусійні питання, які виникають при звільненні від кримінальної відповідальності у зв'язку зі зміною обстановки осіб, котрі вчинили кримінальні правопорушення, передбачені ст. 197-1 Кримінального кодексу України. Аргументовано, що неправомірними є рішення тих судів, які застосовують ст. 48 Кримінального кодексу України лише на тій підставі, що особа позитивно характеризується за місцем проживання, щиро розкаялась у вчиненому кримінальному правопорушенні тощо. Водночас визначено випадки, коли таке застосування є законним та обгрунтованим.

Ключові слова: самовільне зайняття, земельна ділянка, самовільне будівництво, звільнення від кримінальної відповідальності, зміна обстановки, суспільна небезпека, кримінальне правопорушення.

Постановка проблеми. Аналіз судової практики за ст. 197-1 Кримінального кодексу України (далі - КК) «Самовільне зайняття земельної ділянки та самовільне будівнищтво» засвідчує, що однією з їі характерних тенденщій є те, що близько 50 \% винних осіб звільняються від кримінальної відповідальності, з яких більша частина (32 \%) - на підставі ст. 48 КК, котра передбачає звільнення від кримінальної відпові-

(C) Мовчан Р. О., 2020 